\title{
Alden v. Maine: A New Genre of Federalism Shifts the Balance of Power
}

\author{
Jeffrey G. Homrig $\dagger$
}

[It is] a general and indisputable rule, that where there is a legal right, there is also a legal remedy, by suit or action at law, whenever that right is mvaded. ${ }^{1}$

Blackstone's fundamental principle of legal doctrine is no longer true in the United States. In Alden v. Maine, ${ }^{2}$ the Supreme Court held that the Tenth Amendment invests states with the substantive right of sovereign immunity in their own courts from suits brought by individuals under federal law. Furthermore, the Court held that Congress may not use its Article I power to abrogate this immunity. This immunity exists, with few exceptions, even when the federal law in question is a constitutional exercise of federal power vis-à-vis the states. In so holding, the majority erred by attributing more substance to the vagne language of the Tenth Amendment than is due. In addition, it ignored the logical implications of its own

Copyright @2001 Califormia Law Review, Inc. California Law Review, Inc. (CLR) is a California nonprofit corporation. CLR and the authors are solely responsible for the content of their publications.

$\dagger \quad$ J.D. Candidate, School of Law, University of Califomia, Berkeley (Boalt Hall), 2001; B.A., University of California, Berkeley, 1995. I would like to thank Jesse Choper, Earl Warren Professor of Public Law, School of Law, University of California, Berkeley (Boalt Hall) for his insightful comments and valuable revisions, Marina Hsieh, Assistant Professor of Law at the University of Maryland, for her inspiration and encouragement, and Alan Brownstein, Professor of Law at the University of California at Davis, for introducing me to the wonders of constitutional law. In addition, I thank the editors and staff of the California Law Review for their valuable comments and suggested improvements to this Case Note. For encouraging me through all of my endeavors, I thank my parents, Dave and Lisa. Above all, I thank my wife, Staci, without whose love, encouragement, and support this Case Note, and indeed my journey through law school, would not have been possible.

1. 3 WILliam Blackstone, Commentaries *23.

2. 527 U.S. 706 (1999). 
reasoning, and disregarded the detrimental effects likely to follow from the decision.

This flawed holding is all the more troubling because it alters the balance of power between the federal government, state governments, and the people. Against the backdrop of the Court's holding in Seminole Tribe $v$. Florida," this decision erects a "new federalism" that undermines the principles espoused in the Constitution. ${ }^{4}$ The decision weakens the federal government relative to the states, not by balancing power between the federal and state governments, but by enabling states to undercut power properly delegated to the federal government by the Constitution. As a result, Alden not only undermines federal power, but also disenfranchises individuals by placing the right to enforce federal law against the states solely in the hands of the federal government. Thus, this decision will likely frustrate the expectations of those individuals who rely on the protections of federal law by denying them redress for a state's invasion of their rights. In sum, Alden runs contrary to the most basic principles of American government and should be overturned.

In the next Part, I explore the historical foundations of sovereign immunity, the turn of events leading to the adoption of the Eleventh Amendment, and caselaw pertaining to the Eleventh Amendment and congressional power to apply generally applicable laws enacted under Article I to states. In Part II, I present the majority's rationale and decision in Alden. In Part III, I present the dissenters' views, analyze the majority's decision, and conclude that Alden is wrongly decided.

I

Setting the Stage: Sovereign Immunity, Constitutional Foundations and Federal Power

\section{A. Sovereign Immunity}

At its most basic level, sovereign immunity is the right of a government to be free from suits brought without its consent. Long viewed as a fundamental aspect of statehood, sovereign immunity presents difficult

3. 517 U.S. 44 (1996) (holding that Congress does not have authority under Article I to abrogate a state's sovereign immunity from suit in federal court).

4. Federalism itself, of course, is not new. In the 1990 s, the Court decided a string of cases gnarding the rights of states in the federal system. E.g., Printz v. United States, 521 U.S. 898 (1997); United States v. Lopez, 514 U.S. 549 (1995); New York v. United States, 505 U.S. 144 (1992). For a spirited critique of federalism in general, see Frank B. Cross, Realism About Federalism, 74 N.Y.U. L. REV. 1304 (1999). I refer to Alden and Seminole Tribe as creating a "new" federalism because, whereas prior federalism cases have strengthened states vis-à-vis the federal government, I perceive these cases as strengthening states at the expense of the people, as will be explained in greater depth in Part IV.B.2. Florida Prepaid Postsecondary Education Expense Board v. College Savings Bank, 527 U.S. 627 (1999), and College Savings Bank v. Florida Prepaid Postseeondary Education Expense Board, 527 U.S. 666 (1999), both of which were decided on the same day as Alden, fit, I believe, into the latter category. 
questions in the context of our federal system, a system in which previously independent states have subordinated soine, but not all, of their power to a higher entity. In ratifying the Constitution, did these lesser states waive completely their power to invoke sovereign immunity? If some right to immunity was retained, what is the source and scope of this right? And perhaps most importantly, to what extent can these lesser states invoke any such right to sovereign immunity in the face of a legitimate exercise of federal power? These questions have troubled lawmakers and judges alike since the earliest days of the Umion. ${ }^{5}$ Indeed, they are still being resolved. ${ }^{6}$ To place this persisting debate in context, and to understand better the issues at stake, it is instructive to review the conceptual underpinnings of sovereign immunity as it evolved in Western jurisprudence.

\section{Conceptual Foundations of Sovereign Immunity}

Two primary rationales for sovereign immunity have developed over time. The first, the natural law theory, is premised upon the notion that because the state is the fountainhead of the law, others cannot assert the law against the state. As Pufendorf wrote:

[S]ince a king enjoys natural liberty, if he has discovered any fault in a pact of his making, he can of his own authority serve notice upon the other party that he refuses to be obligated by reason of that fault; nor does he have to secure of the other a release from a thing which, of its own nature, is incapable of producing an obligation or right. ${ }^{7}$

Pufendorf added:

A subject, so long as he continues a subject, hath no way to oblige his prince to give him his due, when he refuses it; though no wise prince will ever refuse to stand to a lawful contract. And, if the prince gives the subject leave to enter an action against him, upon such contract, in his own courts, the action itself proceeds rather upon natural equity, than upon municipal laws. ${ }^{8}$

Thus, a sovereign is not bound by its own laws, for its actions are themselves an expression of the law.

The second theory of sovereign immunity is similar, though distinct. Blackstone described the common law theory thus: "[T] he law ascribes to the king the attribute of sovereignty, or pre-eminence. ... Hence it is, that no suit or action can be brought against the king, even in civil matters,

\footnotetext{
5. See infra notes 10-14 and accompanying text.

6. As illustrated by Alden and Seminole Tribe.

7. 2 S. Pufendorf, De Jure Naturae et Gentium LibRi Octo 1342-43 (C. \& W. Oldfather trans., 1934).

8. Id. at $1344-45$.
} 
because no court can have jurisdiction over him. For all jurisdiction implies superiority of power." ${ }^{\prime 9}$ Thus, because the law traditionally grants the state preeminence, a suit cannot be brought against the state without its consent. The implication, however, is that the preeminence conferred upon the state by common law can be rescinded by legislative fiat.

Prior to ratification of the Constitution, the several states, as independent sovereigns, enjoyed the right of sovereign immunity, though under which of these two theories is not clear. With ratification, however, came uncertainty as to the continued vitality of state sovereign immunity.

\section{Chisholm v. Georgia and the Eleventh Amendment}

The debate over the continued existence of state sovereign immunity began even before the Constitution was ratified. As adopted by the Constitutional Convention, Article III provided federal jurisdiction over cases "between a State and Citizens of another State."10 This langnage sparked debate about whether the new Constitution would "humble" states by subjecting them to liability at the hands of individuals. ${ }^{11}$ This issue received considerable attention during the ratification debate. ${ }^{12}$ Indeed, Massachusetts, New Hampshire, New York, North Carolina, Rhode Island, and Virginia each proposed amendments to Article III that would have removed or modified the offending clause. ${ }^{13}$ Nevertheless, the Constitution was ratified without such modification. During the post-ratification debate on the first ten amendments, the issue does not appear to have been discussed. ${ }^{14}$

The issue of state sovereign immunity resurfaced, however, in the first constitutional case decided by the Supreme Court. ${ }^{15}$ In Chisholm $v$. Georgia ${ }^{16}$ the executor of the estate of a merchant who had done business with the State of Georgia during the Revolutionary War filed a suit in the Supreme Court to recover damages under a contract made with the state. ${ }^{17}$ The state sought dismissal of the action for lack of jurisdiction. ${ }^{18}$ The Court, with each justice writing separately, held that the Constitution permitted a federal court to adjudicate an action brought by an individual against an unconsenting state. The Court premised its holding on the

9. 1 William Blackstone, Commentaries *234-35.

10. U.S. Const. art. III, $\S 2$, cl. 6.

11. See William A. Fletcher, A Historical Interpretation of the Eleventh Amendment: $A$ Narrow Construction of an Affirmative Grant of Jurisdiction Rather Than a Prohibition Against Jurisdiction, 35 STAN. L. REv. 1033, 1047-48 (1983).

12. Id. at 1049-50.

13. Id. at 1051-52.

14. Id. at 1054.

15. Id.

16. 2 U.S. 419 (1793).

17. Fletcher, supra note 11, at 1055.

18. Chisholm, 2 U.S. at 430 (Iredell, J., dissenting). 
Article III language that had given rise to such consternation during the ratification debates: "The judicial power shall extend to controversies between a State and Citizens of another State."19

The Chisholm decision caused such discord that, within months, Congress approved and ratified the Eleventh Amendment, limiting such jurisdiction to actions in which the state is a plaintiff. ${ }^{20}$ The text of the amendment is as follows:

The Judicial power of the United States shall not be construed to extend to any suit in law or equity, commenced or prosecuted against one of the United States by Citizens of another State, or by Citizens or Subjects of any Foreign State. ${ }^{21}$

Although the amendment's language appears to be designed merely to restrict the scope of jurisdiction conferred by the "between a State and Citizens of another State" language of Article III, the proper scope to be given the amendment has been the subject of much debate.

\section{Eleventh Amendment Jurisprudence}

The text of the Eleventh Amendment appears to limit only suits agaimst a state brought by a citizen of another state. But im Hans $v$. Louisiana, ${ }^{22}$ the Supreme Court held that the Eleventh Amendment also bars a suit against a state brought under federal law by a citizen of that state. The Court remarked: "That a state cannot be sued by a citizen of another state, or of a foreign state, on the mere ground that the case is one arising under the constitution or laws of the United States, is clearly established by the decisions of the court in several recent cases."23 The Court acknowledged that the text of the Eleventh Amendment appears not to apply to citizens of the state being sued, but rejected this interpretation as inconsistent with the view that states retained an inviolable immunity, which predominated at the time the Constitution was enacted. ${ }^{24}$ The Court then interpreted the phrase "concurrent with the courts of the several states," included in the Judiciary Act of 1875, as restricting federal jurisdiction to be no broader than state jurisdiction. ${ }^{25}$ Because state and federal courts enjoy the same jurisdictional scope under the Act, the Act could not be read to confer "any new and strange jurisdictions," such as overriding a state's traditional right of sovereign immunity. ${ }^{26}$ The point is critical,

19. Id. at 467 (Cushing, J.).

20. See William A. Fletcher, The Diversity Explanation of the Eleventh Amendment: A Reply to Critics, 56 U. CHI. L. Rev. 1261, 1269-71 (1989).

21. U.S. ConsT. amend. XI.

22. 134 U.S. 1 (1890).

23. Id. at 10.

24. See id. at 11-12.

25. See id. at 18.

26. Id. 
however, not for what it says, but for what it does not say: the fact that the Court based this argument on the language of the Judiciary Act, an act of Congress, rather than on the constitutional structure itself, suggests that Congress may have some power to override state sovereigu immunity should it choose to do so. Nevertheless, the Court determined that a state could assert sovereign immunity against any plaintiff in federal court under any cause of action.

Ninety-nine years later, the Court changed course. In Pennsylvania v. Union Gas Company, ${ }^{27}$ the Court held that the Commerce Clause grants Congress the power to abrogate state sovereigu immunity. ${ }^{28}$ Rejecting Justice Scalia's dissenting view that under Hans, Congress does not have the power to abrogate state sovereign immunity, the Union Gas majority held that the Judiciary Act of 1875 in Hans merely "gave effect" to the power encompassed by Article III. ${ }^{29}$ Thus, the Court ruled that Hans did not establish absolute state sovereign immunity, and did not "begin to address the question whether other congressional enactments, not designed simply to implement Article III's grants of jurisdiction, may override States' immunity." 30 The majority turned to Fourteenth Amendment immunity jurisprudence, noting that in Fitzpatrick v. Bitzer ${ }^{31}$ the Court found that Congress has the power to abrogate state sovereign immunity in the exercise of power granted by Section Five of the Fourteenth Amendment. ${ }^{32}$ The Court stated that the Fourteenth Amendment gives Congress this power because, when Congress exercises authority pursuant to Section Five, "'it is exercising that authority under one section of a constitutional Amendment whose other sections by their own terms embody limitations on state authority." ${ }^{\prime 33}$ The majority likened the Commerce Clause to the Fourteenth Amendment in that "the Commerce Clause with one hand gives power to Congress while, with the other, it takes power away from the States. ${ }^{34}$ In other words, just as the Fourteenth Amendment gives Congress the power to abrogate state sovereign immunity, so too does the Commerce Clause. Finally, the Court equated ratification of the Constitution with waiver:

Because the Commerce Clause withholds power from the States at the same time as it confers it on Congress, and because the congressional power thus conferred would be incomplete without the authority to render States liable in damages, it inust be that, to

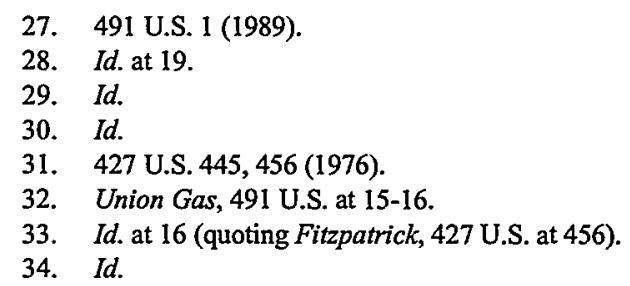


the extent that the States gave Congress the authority to regulate commerce, they also relinquished their immunity where Congress found it necessary, in exercising this authority, to render them liable. The States held hable under such a congressional enactment are thus not "unconsentimg"; they gave their consent all at once, in ratifying the Constitution containing the Commerce Clause, rather than on a case-by-case basis. ${ }^{35}$

Thus, under Union Gas, Congress had the power to abrogate state sovereign immunity when exercising the power granted it by the Commerce Clause.

Just seven years later, the Court reversed itself. In Seminole Tribe of Florida v. Florida, ${ }^{36}$ the Court held that Congress cannot use its Article I power to abrogate state sovereign immunity in federal court. The Court based its decision on the implicit scope of the Eleventh Amendment, finding that "the background principle of state sovereign immunity embodied in the Eleventh Amendment is not so ephemeral as to dissipate when the subject of the suit is an area ... that is under the exclusive control of the Federal Government." The Court stated that "the Eleventh Amendment restricts the judicial powver under Article III, and Article I cannot be used to circumvent the constitutional limitations placed upon federal jurisdiction." ${ }^{\text {"38 }}$ In practice, the decision gives states the right to invoke sovereign immunity agamst federal causes of action created pursuant to federal Article I power when brought in federal courts. Until Alden, however, whether states could assert sovereign immunity against such causes of action brought in their own courts remained to be decided.

\section{B. Federal Power to Hold States to Generally Applicable Laws}

In National League of Cities v. Usery ${ }^{39}$ the Court held that Congress did not have the power to bind states to generally applicable laws when the laws would interfere with the "core functions" of a state. ${ }^{40}$ The case arose from a challenge to the Federal Labor Standards Act (FLSA) Amendments of 1974, which extended the provisions of the FLSA to include all state and municipal employees. ${ }^{41}$ In applying its "core functions analysis," the Court stated that "[t] he [Tenth] Amendment expressly declares the constitutional policy that Congress may not exercise power in a fashion that impairs the States' integrity or their ability to function effectively in a federal

35. Id. at $19-20$.

36. 517 U.S. 44 (1996).

37. Id. at 72 .

38. Id. at 45 .

39. 426 U.S. 833 (1976).

40. Id. at 845 ("We have repeatedly recognized that there are attributes of sovereignty attaching to every state government which may not be impaired by Congress ....").

41. Pub. L. No. 93-259, § 6, 88 Stat. 55, 58 (codified at 29 U.S.C. $\S 203(\mathrm{e})(2)(C)$ (1994) (stating that the Act applies to "any individual employed by a State")). 
system." ${ }^{.42}$ The core functions analysis adopts the premise that Congress cannot regulate states as states. ${ }^{43}$ Finding that the FLSA would "impermissibly interfere with the integral governmental functions" of states, ${ }^{44}$ the Court declared the 1974 amendments to be unconstitutional.

Just nine years later, in Garcia v. San Antonio Metropolitan Transit Authority, ${ }^{45}$ the Court overturned National League of Cities, holding that in making the wage provisions of the FLSA applicable to state employees, Congress acted within the power conferred upon it by the Constitution. ${ }^{46}$ Justice Blackmun, the swing vote in National League of Cities and the key meinber of the new majority, rejected the core functions analysis as unworkable. ${ }^{47}$ Instead, he asserted that the participation of state representatives and senators in Congress ensured sufficient state participation to satisfy the Tenth Amendment. ${ }^{48} \mathrm{He}$ concluded that "we need go no further than to state that we perceive nothing in the overtime and minimum-wage requirements of the FLSA ... that is destructive of state sovereignty or violative of any constitutional provision." ${ }^{.49}$ Thus, the Garcia Court extended the FLSA to create a federal right protecting state employees froin being paid unfair wages and being forced to work extended hours without adequate coinpensation by state employers.

Immediately prior to Alden, then, the state of the law stood thus: Congress had the power to hold states to the provisions of the FLSA, but did not have the power to provide individuals with a private right of action to uphold provisions of the FLSA against states in federal court. Whether, and to what extent, Congress could provide such rights of action in state courts was an open question. Three years after Seminole Tribe, the Supreme Court provided the answer in Alden.

\section{II \\ ALDEN V. MAINE \\ A. Facts and Procedural History}

Following a dispute regarding overtime pay, John Alden and sixty-six other probation officers filed suit in federal court alleging that their

42. Nat'l League of Cities, 426 U.S. at 843.

43. Id. at 845 . The Court cited an example of such core functions:

The power to locate its own seat of government, and to determine when and how it shall be changed from one place to another, and to appropriate its own public funds for that purpose, are essentially and peculiarly state powers. That one of the original thirteen states could now be shorn of such powers by an act of Congress would not be for a moment entertained.

Id. (quoting Coyle v. Oklahoma, 221 U.S. 559, 565 (1911)).

44. Id . at 851 .

45. 469 U.S. 528 (1985).

46. Id. at 554,557 .

47. Id. at 531 .

48. Id. at 551 .

49. Id. at 554 . 
employer, the State of Maine, had violated the FLSA..$^{50}$ During the course of federal litigation, the Supreme Court decided Seminole Tribe and, as a result, the district court dismissed the claims in response to Maine's assertion of sovereign immunity. The officers then filed an identical action in state court, which the trial court also dismissed on grounds of sovereign immunity. The Supreme Judicial Court of Maine affirmed, reasoning: "If Congress cannot force the states to defend in federal court against claims by private individuals, it similarly cannot force the states to defend in their own courts against these saine claims. ${ }^{.51}$

\section{B. The Supreme Court's Decision}

Writing for the majority, Justice Kennedy relied on original intent, constitutional structure, and the practical impacts of suability on state government to reach the conclnsion that the federal government caunot use its Article I power to abrogate the constitutionally protected sovereign immunity of the states. ${ }^{52}$ Contrary to the implications of the phrase "Eleventh Amendment immunity," sovereign immunity "is a fundamental aspect of the sovereignty which the States enjoyed before the ratification of the Constitution," and which the Constitution explicitly recognizes. ${ }^{53}$ To the extent that the Constitution and constitutional amendments have not subsuned this immunity, it is retained by the states. ${ }^{54}$ The Tenth Amendment removes any doubt about state sovereignty when it relegates all matters not covered by the Constitution to state power. ${ }^{55}$

\section{Original Intent}

Jnstice Kennedy argued that the founding generation considered immunity from suit to be a central feature of a sovereign's dignity. ${ }^{56} \mathrm{He}$ supported this claim, in part, by citing the views of several members of the founding generation, includimg Alexander Hamilton, who made clear his belief that sovereign immunity is inherent in the nature of sovereignty. ${ }^{57} \mathrm{As}$ further support for this understanding of original intent, Justice Keunedy noted that the constitutional conventions of New York and Rhode Island

50. Alden v. State, 715 A.2d 172, 173 (Me. 1998).

51. Id. at 174 .

52. Alden v. Maine, 527 U.S. 706,754 (1999). Although the term "sovereign immunity" implicates both freedom from federal regulation and freedom from suits brought under federal law, Alden addresses only the latter issue. For an analysis of states' right to be free from regulation under the FLSA, see generally National League of Cities v. Usery, 426 U.S. 833 (1976) (barring application of the FLSA to states), and Garcia v. San Antonio Metropolitan Transit Authority, 469 U.S. 528 (1985) (overruling National League of Cities).

53. Id. at 713.

54. Id.

55. Id.

56. Id. at 715.

57. Id. at 716-18. 
both sought assurances that the Constitution did not deprive states of immunity ${ }^{58}$ Finally, he reasoned that the Constitution's silence with respect to state sovereign immunity "is best explained by the simple fact that no one, not even the Constitution's most ardent opponents, suggested the document might strip the States of the immunity." "T9 This combination of statements and silence, he argued, unakes it clear that a state's right to be free from suit was widely understood. ${ }^{60}$

Justice Kennedy's claim that the founding generation considered immunity essential to the sovereign's dignity provided the basis for his interpretation of the Court's holding in Chisholm v. Georgia. ${ }^{61}$ He noted that while each justice in the Chisholm majority favored a different rationale for the decision, they all believed that the case arose within the jurisdiction granted by the literal text of Article III. ${ }^{22}$ Justice Kennedy also emphasized that at least one nember of the Chisholm majority saw the decision as unpopular, which indicated that the decision ran contrary to the established understanding of the Constitution. Following the Chisholm decision the nation erupted in outrage. ${ }^{63}$ Within days, both houses of Congress had introduced a version of the eventual Eleventh Amendinent, and in approximately two months the amendinent was approved and forwarded to the states. ${ }^{64}$ Additionally, Justice Kennedy noted that the text of the Eleventh Amendinent "did not redefine the federal judicial power but instead overruled the Court." ${ }^{265}$ Rather than codify the traditional understanding of sovereign immunity, Congress chose "to address the specific provisions of the Constitution that had raised concerns during the ratification debates and formed the basis of the Chisholm decision."166 In sum, Justice Kennedy argued that the outrage following the Chisholm decision, the swift enactment of the Eleventh Amendinent, and the text of the amendinent itself demonstrate that the Constitution was not intended to strip states of their sovereigu immunity. ${ }^{67}$

The Court, according to Justice Kennedy, has consistently viewed the enactment of the Eleventh Amendinent as "conclusive evidence" that the Chisholm Court misinterpreted the Constitution. ${ }^{68}$ Because of its understanding that the Eleventh Amendment only restored the original meaning

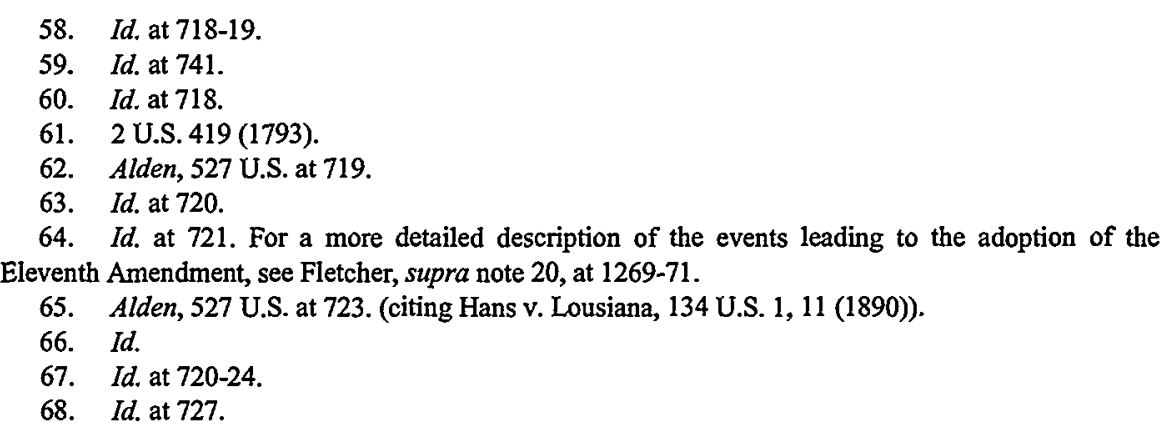


of the Constitution, the Court does not look to the letter of the Eleventh Amendment to define the scope of state immunity ${ }^{69}$ Rather, the Court refers to "history and experience, and the established order of things," guidance as to whether sovereign immunity applies.

\section{Constitutional Structure}

Justice Kennedy argued that the federal system protects state sovereignty in two ways. First, "it reserves to them a substantial portion of the Nation's primary sovereignty, together with the dignity and essential attributes inhering in that status." $"$ Second, it provides for concurrent statefederal authority, rather than a system in which the federal government regulates through state governments. ${ }^{72}$ These two points establish that, within the sphere not delegated to the federal government, states are not "mere provinces or political corporations," but rather sovereign entities. ${ }^{73}$

According to Justice Kennedy, Hans and other cases in which the Court took an expansive view of sovereign immunity confirm that sovereign immunity derives from the original Constitution, rather than the Eleventh Amendinent itself. ${ }^{74}$ Thus, the "scope of the States' immunity from suit is demarcated not by the text of the Amendinent alone but by fundamental postulates implicit in the Constitutional design." 75 These postulates coine in two parts: "first, that each State is a sovereign entity in our federal system; and second, that 'it is inherent in the nature of sovereignty not to be amenable to the suit of an imdividual without its consent." $" 76$

To evaluate the plaintiff's right, or lack thereof, to bring a FLSA action against a state requires the Court to determine whether Congress has the power under Article I to force states to entertain suits agaimst themselves in their own courts. ${ }^{77}$ In answering this question, Kennedy focused on whether "compelling evidence" exists that the States surrendered this power to Congress when they ratified the Constitution. ${ }^{78} \mathrm{He}$ rejected the contention that federal law "by its own force" overrides state sovereign immunity. ${ }^{79}$ Rather, Congress's attempt to eviscerate this power merely raises the question of whether such an act falls within the Constitutional

69. Id. (citing Hans, 134 U.S. at 13).

70. Id. (citing Hans, 134 U.S. at 14).

71. Id. at 714 .

72. Id.

73. Id. at 715 .

74. Id. at 728 .

75. Id. at 729 .

76. Id. (quoting Hans, 134 U.S. at 13).

77. Id. at 730 .

78. Id. at 730-31 (quoting Blatchford v. Native Village, 501 U.S. 775, 781 (1991)).

79. Id. at 732 . 
design. ${ }^{80}$ Justice Kennedy also rejected the argument that the Necessary and Proper Clause provides Congress with such power on the grounds that the Clause cannot be used to achieve an objective outside the enumerated powers of Congress. ${ }^{81}$

To determine the limitations imposed by the constitutional structure, the Court must look to "the essential principles of federalism and to the special role of the state courts." ${ }^{92}$ Despite broad grants of power to Congress, the federal government must treat states consistently with "their status as residuary sovereigns and joint participants in the governance of the Nation." ${ }^{183}$ Thus, federal power to rescind state immumity in state courts would in some ways be more offensive than federal power to rescind state immunity in federal courts because "the immunity of a sovereign in its own courts has always been understood to be within the sole control of the sovereign itself." $\$ 4$

\section{Practical Impacts of State Sovereignty From Suits Under Federal Law}

In reaching its holding in Alden, the Court argued that sovereign immunity should be recognized in this context because to hold otherwise might result in financial harm to states. ${ }^{85}$ The majority warned that "[a] general federal power to authorize private suits... would place unwarranted strain on the States' ability to govern in accordance with the will of their citizens." ${ }^{\prime 86}$ Furthermore, given the holding in Seminole Tribe v. Florida ${ }^{87}$ allowing Congress to abrogate state immunity in state courts would enable the federal government to "wield greater power in the state courts than in its own judicial instrumentalities." 98 This outcome, the majority contended, is anathema. "We are aware of no constitutional precept that would admit of a congressional power to require state courts to

80. Id. at 731 .

81. Id. at 732-33. Justice Kennedy quoted language from an "analogous context" in which the Court challenged congressional power to pass laws to "carry into execution the Commerce clause," which laws intrude on matters delegated to states by the Constitution:

When a " $\mathrm{La}[\mathrm{w}]$... for carrying into Execution" the Commerce Clause violates the principle of state sovereignty reflected in the various constitutional provisions... it is not a "La[w] ... proper for carrying into Execution the Commerce Clause," and is thus, in the words of The Federalist, "mercly [an] ac[t] of usurpation" which "deserve[s] to be treated as such."

Id. (quoting Printz v. United States, 521 U.S. 898, 923-24 (1997)).

82. Id. at 748 .

83. Id.

84. Id. at 749 .

85. Id. at 750 .

86. Id. at $750-51$.

87. 517 U.S. 44 (1996). Congress nray not use its Article I power to abrogate state sovereign immunity in federal court. See supra notes 36-38 and accompanying text.

88. Alden, 527 U.S. at 752. 
entertain federal suits which are not within the judicial power of the United States and could not be heard in federal courts." 89

Not surprisingly, the Court downplayed the potential repercussions of its holding on federal authority. The majority preenuptively addressed concerns regarding enforcement of valid federal law against states by noting that several limitations to immunity exist. First, states retain immunity only to the extent that they do not waive it, which they may do explicitly or implicitly by their actions. ${ }^{90}$ By ratifying the Constitution and its accompanying ainendments, states consented to some types of suits, such as those brought by other states or by the federal government. ${ }^{91}$ Thus, the federal government itself retains the power to enforce the FLSA through litigation on behalf of individuals. In this same vein, states surrendered immunity with respect to the provisions of the Fourteenth Amendment. ${ }^{92}$ Second, the majority notes that immunity does not apply to suits against state subdivisions, such as inunicipalities and school boards. Thus, in the majority's view, Alden's effects on individual rights will be relatively minor; certainly the harm to individuals cannot justify the threat to a state's fiscal health posed by unrestrained enforcement of federal law.

\section{III \\ ANALYSIS \\ A. Analytical Shortcomings of the Majority Opinion}

In his spirited dissent, Justice Souter challenged the majority's conclusions, commenting that "if the [majority's] reasoning is correct, the Eleventh Amendment itself was unnecessary." evidence that the Tenth Amendment constitutionalized a concept of sovereign immunity as inherent in the notion of statehood."94 Justice Souter's dissent is simply more compelling than the niajority's argument. Indeed, in each of the areas upon which Justice Kennedy drew to support his conclusion-original intent, constitutional structure, and potential impacts on state governments-he was unconvincing.

\section{Original Intent}

In holding that the Tenth Amendment conferred a substantive right of sovereign immunity from suits under federal law upon states, Justice Kennedy argued that at the time the Constitution was framed there was a generally held belief that unconsenting states had the right to be free froin

89. Id. at 754.

90. Id. at 755 .

91. Id.

92. Id. at 756.

93. Id. at 761 .

94. Id. 
suit. The Tenth Amendment gave constitutional substance to this existing right by stipulating that all powers and rights held by states, and not explicitly or implicitly conferred upon the federal government by the Constitution, remained within the power of the states.

In dissent, Justice Souter rejected the majority's claim that the founding generation understood states to possess sovereign immunity by immutable right. He argued that " $[t]$ here is almost no evidence that the generation of the Framers thought sovereign immunity was fundamental in the sense of being unalterable. ${ }^{.95}$ Therefore, he argued, any sovereign immunity remaining with the states must be based on some other theory.

Justice Souter described two theories for the existence of sovereign immunity. The first, based on common law, derives from the ancient tradition that the king, as sovereign, could not be sued because "no court can have jurisdiction over him. ${ }^{.96}$ The second theory, based on natural law, derives from the nature of the king as lawmaker.

"[I]f the prince gives the subject leave to enter an action against

him, upon such contract, in his own courts, the action itself proceeds rather upon natural equity, than upon the municipal laws." For the end of such action is not to compel the prince to observe the contract, but to persuade him. ${ }^{97}$

In contrast to the common law justification, this theory grows out of "general theoretical principles."

According to Justice Souter, these varying rationales for sovereigu immunity left states without gnidance as to whether they possessed immunity upon independence. ${ }^{99}$ While some states retained preRevolutionary constitutions lacking immunity provisions, others enacted such provisions. ${ }^{100} \mathrm{He}$ argued that Alexander Hamilton was the only "absolutist" supporter of state sovereign immunity during the constitutional convention, while James Madison, Edmund Randolph, and James Wilson, among others, each held some less absolute view regarding state sovereigu immunity. ${ }^{101}$ And he noted that the New York ratification convention proposed amendments that would make clear that the federal courts could not entertain a suit against a state. "Whether that amendment was meant to alter or to clarify Article III as ratified is uncertain, but regardless of its

95. Id. at 764.

96. Id. at 765 (quoting I William Blackstone, Commentaries *242).

97. Id. at 766 (quoting 1 Blackstone, supra note 96, at *243 (quoting 2 S. PufENdorr, DE Jure Naturae et Gentium Libri Octo $1344-45$ (C. \& W. Oldfather trans., 1934))).

98. Id. at 767.

99. Id. at 769 .

100. Id. at 769-70.

101. Id. at 773-77 
precise intent, New York's response... shows that there was no consensus at all on the question of state suability."102

Turning to the Chisholm decision, Justice Souter remarked that since the Bill of Rights had been ratified only two years prior to the decision, "if the Tenth Amendment had been understood to give federal constitutional status to state sovereign immunity ... one would be certain to find such a development inentioned somewhere in the Chisholm writings." ${ }^{\prime 103}$ In fact, not one of the opinions mentioned the Tenth Amendment, and "[n]ot a single Justice suggested that sovereign immunity was an inherent and indefeasible right of statehood." 104 Moreover, even Justice Iredell, the Chisholm dissenter relied upon by the majority, viewed sovereign immunity as a common law doctrine rather than an immutable right. ${ }^{105}$

The majority's evidence of this widespread belief is unpersuasive. First, although Justice Souter's clain that there is virtually no evidence of an absolutist view of state sovereign immunity may be overstated in light of Hamilton's views, Souter's examples do demonstrate that there appears to have been no consensus regarding the extent of pre-Constitution sovereign immunity. This lack of consensus is important, because it shows that, however strongly held, Hamilton's absolutist view was merely one of several views that existed at the time the Constitution was enacted. Second, and more fundamental, the evidence Justice Kennedy offered in support of his conclusion emerged from a debate about whether Article III abrogated a state's sovereign immunity with respect to suits brought under diversity jurisdiction. ${ }^{106}$ As Justice Kennedy himself recognized, states feared suits to collect on their wartime debts, ${ }^{107}$ and these causes of action arose from the individual states' common law of contracts. That debate shonld be distinguished from the issue of whether states retained immunity in the face of a valid federal law. ${ }^{108}$ Finally, one shonld not read too much into the

\footnotetext{
102. Id. at 779 .

103. Id. at 781 .

104. Id. at 789 .

105. Id.

106. See Fletcher, supra note 11, at 1049-52.

107. Alden, 527 U.S. at 716 (citing Nevada v. Hall, 440 U.S. 410,418 (1979)).

108. Comparing suits brought under federal law with suits brought under common law (as was the case in Clisholm) in the course of examining the scope of the Eleventh Amendment, Professor Fletcher writes:
}

Suits brought under federal law were something else again. In these suits, the issue was not whether a state should be bound by non-federal law (including both local state law and common law, which it could change or depart from whenever it chose). Rather, the issue was whether a state could be judicially compelled to obey the law of a superior sovereign. The federal law question, unlike the Chisholm question, was whether the states in subscribing to the Constitution gave up their sovereign immunity to suits brought under the new federal law that was created or authorized by the new Constitution. These questions are so different that it is implausible that the adopters of the Eleventh Amendment should have thought that the answer to the first question necessarily entailed the answer to the second.

Fletcher, supra note 20, at 1297. 
Constitution's silence with respect to state sovereign immunity. Several factors, including erosion of attributes of true sovereignty and the states' surrender of sovereign immunity in other contexts, suggest that suits by individuals against states are permissible under federal question jurisdiction. ${ }^{109}$

\section{Constitutional Structure}

Following his rebuttal of Justice Kennedy's factual and legal account, Justice Souter explored in greater detail the implications of the two views of sovereign immunity prevailing at the time the Constitution was enacted. Specifically, Justice Souter argued that neither of the prevailing views justifies a state's immunity from a constitutional exercise of congressional power. The rationale supporting sovereign immunity is important because sovereign immunity based upon a common law doctrine would only carry the weight of common law. ${ }^{110}$ It could thus be abrogated by affirmative, constitutional exercises of federal power, such as the FLSA. Even if a natural law right to sovereign immunity were established, "under the natural law theory, sovereign immunity may be invoked only by the sovereign that is the source of the right upon which the suit is brought."111 Because under Garcia the FLSA was a constitutional exercise of federal power, and because the source of the law was federal and not state, Maine could not lay claim to sovereign immunity on the basis of a natural law theory of immunity. ${ }^{112}$ Thus, im Justice Souter's view, even assuming that the Tenth Amendment did constitutionalize the prevailing opimions regarding immunity, neither rationale would bar Congress from abrogating this immunity.

Without conceding that the Tenth Amendment constitutionalized the existing right of sovereign immunity, it is useful to consider what effect such constitutionalization would have had on congressional power to provide for individual remedies against states. If the Tenth Amendment does preserve traditional state sovereign immunity, what is the source and scope of this right? Although it implicitly accepts sovereign immunity as a fundamental aspect of statehood, the majority fails to docunient the source of this right beyond a widely held belief in its existence. Nevertheless, three distinct possibilities are apparent.

The first possibility is that the Tenth Amendment established sovereign immunity as an indefeasible aspect of statehood within the federal system. Although Justice Kennedy describes sovereign immunity as possessing these characteristics, he does not explain why the federal

109. See Fletcher, supra note 11, at 1072-74.

110. Alden, 527 U.S. at 798.

111. $\quad I d$. at 796.

112. Id. at 798 . 
structure compels a finding that a state can assert sovereign immunity against a claim premised upon federal law. Rather, he simply states that "each State is a sovereign entity" and that "it is inherent in the nature of sovereignty not to be amenable to the suit of an individual without its consent."113 At least two factors suggest the opposite conclusion.

First, prior to the adoption of the Constitution, the several states existed as wholly sovereign members of a federation. The federation itself lacked power over states; indeed, "national" legislation required approval of a two-thirds majority of member states. ${ }^{114}$ Due to this lack of central authority, state law reigned supreme. By enacting the Constitution, however, states gave up a portion of their sovereignty to become members of the federal system. Governed by the Constitution, and its all-important Supremacy Clause, states for the first time since Independence saw their power subsunied, in certain specified areas, under that of a higher power. Logically speaking, states could not have "retained" sovereign immunity vis-à-vis the laws of a higher power because such higher power simply did not exist prior to the Constitution. Thus, state immunity applicable to federal law would have had to have been created by the Constitution itself. Given the diverse viewpoints of the founding generation regarding the scope of sovereign immunity held by states prior to the Constitution's enactinent, the argument that the framers created this new immunity without explicitly defining it in the Constitution is simply not persuasive.

Second, the fact that the Constitution grants Congress the power to subject states to generally-applicable laws, such as the FLSA (as Garcia held), suggests that states retain no power in this area. In the words of one commentator, "the Constitution gave Congress, not the states, complete sovereignty to regulate interstate commerce. In other words, in regulating the states through the FLSA ... Congress is not interfering with the states' sovereign immunity because they have no sovereignty in this area."115 Justice O'Counor, a member of the Alden majority, has made this same point in another context: "If a power is delegated to Congress in the Constitution, the Tenth Amendinent expressly disclaims any reservation of that power to the states. ${ }^{\text {116 }}$ But this point is best expressed in the words of the founders themselves. As Alexander Hamilton wrote,

the laws of the Confederacy, as to the enumerated and legitimate objects of its jurisdiction, will become the SUPREME LAW of the land.... Thus, the legislature, courts, and magistrates, of the respective members, will be incorporated into the operations of the

113. Id. at 730 (quoting Seminole Tribe v. Florida, 517 U.S. 44, 54 (1996)).

114. See Maxwell A. Miller and Mark A. Glick, The Resurgence of Federalism: The Case for Tax-Exempt Bonds, 1 Tex. Rev. L. \& Pol. 25, 32-33 (1997).

115. Scott Fruehwald, If Men Were Angels: The New Judicial Activism in Theory and Practice, 83 MaRQ. L. REV. 435, 481 (1999).

116. New York v. United States, 505 U.S. 144, 156 (1992). 
national government as far as its just and constitutional authority extends; and will be rendered auxiliary to the enforcement of its laws. ${ }^{17}$

Or, $\mathrm{m}$ the words of James Madison, "[i]n [a federal system], the local or municipal authorities form distinct and mdependent portions of the supremacy, no more subject, within their respective spheres, than the general authority is subject to them, within its own sphere."118 Because the Court has upheld the application of the FLSA to states as a constitutional exercise of federal power, the statements of Madison and Hamilton suggest that states have no right, constitutional or otherwise, to interfere with this power by assertimg sovereign immunity. In sun1, there appears to be little evidentiary support for, and, indeed, compelling evidence against, reading an absolute right of state sovereign immunity into the Constitution's structure.

The second and third possibilities for the source of sovereign immunity as a fundamental aspect of statehood consist of reading the Constitution and its amendinents as preserving state sovereign immunity as it existed at the time the Constitution was enacted. Given the above discussion of absolute immunity, these possibilities reflect a more reasonable understanding of the source and scope of any state sovereign immunity existing within the constitutional framework. In fact, even Justice Kennedy acknowledged their probability, perhaps unwittingly, when he wrote that " $[t]$ he more natural inference is that the Constitution was understood, in light of its history and structure, to preserve the States' traditional immunity from private suits." 119 As Justice Souter pointed out, views regarding the source and scope of immunity existing at the time of the Constitution's enactment differ greatly. Nevertheless, two views appear to have predominated: common law immunity and natural law immunity. ${ }^{120}$

The second possibility, then, assumes that the Tenth Amendinent confirmed the states' retention of common law immunity. As Justice Souter made clear, such a right would have no impact with respect to federal law, for Congress has the power to override common law doctrines within its delegated authority. ${ }^{121}$ The third possibility, assuming that the Tenth Amendinent constitutionalized natural law immunity, yields no greater state power. Because the source of federal law is the federal government, and not the state government, natural law immunity does not offer states any protection im this context. ${ }^{122}$

117. The Federalist No. 27, at 169-70 (Alexander Hamilton) (Sherman F. Mittell ed., 1938).

118. The FEDERALIST No. 39, at 249 (James Madison) (Sherman F. Mittell ed., 1938).

119. Alden v. Maine, 527 U.S. 706, 724 (1999) (emphasis added).

120. Id. at 763-69.

121. Id. at 798; see also text accompanying notes 9,110.

122. Alden, 527 U.S. at 798; see also text accompaning notes 7-8, 110-111. 
Justice Kennedy responded to Justice Souter's critique by disparaging the natural law reference, writing that "the contours of sovereign immunity are determined by the founders' understanding, not by the principles or limitations derived from natural law." 123 But Justice Kennedy's rejoinder missed its mark. In pointing out that the "founders' understanding" is the key to interpreting sovereign immunity, he inadvertently made Justice Souter's case. Accepting Justice Souter's conviction that the founders understood sovereign immunity to be premised either upon natural law or common law, it naturally follows that, if the Tenth Amendinent retained the states' existing immunity, such immunity would reflect the "principles or limitations" of one of these views. To argue otherwise is to discount, not credit, the founders' understanding of state sovereign immunity.

\section{Potential Impacts on State Governments}

Justice Keunedy's argument that abrogation of state sovereign immunity would negatively impact state functions bears a striking resemblance to the discredited core functions analysis used to strike down the FLSA's application to states in National League of Cities. ${ }^{124}$ As im Alden, the National League of Cities Court considered the FLSA's effects on a state's ability to make decisions and to allocate its limited resources in response to the needs of its constituents. ${ }^{125}$ The Court found these and other concerns sufficiently persuasive to hold that Congress did not have the constitutional authority to apply the FLSA to state governments. ${ }^{126}$ Although not identical, Justice Kennedy's analysis of the impact of suability on states and the core functions analysis of National League of Cities share the same basic premise: congressional action that forces states to alter their internal structures in ways that affect fiscal decision making is outside the scope of federal power.

Despite the usefulness of this basic premise to the majority's position, it was rejected in Garcia. In that case, the Court found the burdens insufficient to warrant a restriction on federal power and held that Congress has the potver to apply the FLSA to state government. ${ }^{127}$ Given that the Alden holding does not disturb Garcia, this argument is unpersuasive at best. ${ }^{128}$

123. Alden, 527 U.S. at 734.

124. Compare Nat'l League of Cities v. Usery, 426 U.S. 833, 847 (1976) ("[T]he Act displaces state policies regarding the manner in which they will structure dehivery of these governmental services which their citizens require."), with Alden, 527 U.S. at 750-51 ("A general federal power to authorize private suits for inoney damages would place unwarranted strain on the States' ability to govem in accordance with the will of their citizens.").

125. Nat'l League of Cities, 426 U.S. at 846.

126. Id. at 855 .

127. Garcia v. San Antonio Metro. Transit Auth., 469 U.S. 528, 554 (1985).

128. Justice Souter attacked the majority's "impact on state government" analysis directly, stating: 
Furthermore, the argument appears irrelevant. As Justice Kennedy explicitly stated, Alden does not prevent the federal government from undertaking an action against a state on behalf of an injured individual. ${ }^{129}$ Presumably, such suits for money damages would be just as disruptive to state decision making as those brought by individuals.

To summarize, Jutice Kennedy's "one view" account of sovereign immunity fails to acknowledge the existence of varying beliefs among the founding generation. Even acceptance of Kennedy's view that the Tenth Amendment constitutionalized state sovereign immunity is not sufficient to support his conclusion. The text of the Tenth Amendinent does not support the creation of an absolute right of immumity, and neither of the rationales for immunity is sufficient to overcome Congress's constitutional enactment of the FLSA. Finally, Justice Kennedy's importation of the basic premise of an analysis previously rejected by the Court, and, to great extent, irrelevant to the situation at hand, adds little to his argument. In sum, Justice Kennedy's analysis is not persuasive.

\section{B. Threats to the Constitutional Structure}

A cynic might argue that the Alden majority, dissatisfied with the outcome in Garcia and unable to garner the votes needed to overturn that decision, sought to work the same effect through different means. ${ }^{130}$ Whether or not so inotivated, the majority certainly achieved that effect by "discovering" this right more than 200 years after the Constitution was enacted. ${ }^{131}$ By limiting enforcement of the FLSA and similar federal laws to federal enforcement vis-à-vis states, Alden eviscerates their substance. As Justice Souter noted, it was the very impracticality of federal government

So long as the citizens' will, expressed through state legislation, does not violate valid federal law, the strain will not be felt; and to the extent that state action does violate federal law, the will of the citizens of the United States already trumps that of the citizens of the State.

Alden, 527 U.S. at 803 (Souter, J., dissenting).

129. Id. at 755 .

130. See Charles Fried, Opponents of Federalism are Mired in Time Warp, WaLl ST. J., May 16, 2000, at A26:

How does it make sense to say that Congress may impose wage and hours laws on states, but that state employees-unlike any other workers - cannot sue in any court to enforce that right? ... [This] nonsensical result [] can only have come about because the majority of the court lacked the confidence (or the votes) to simply say that the law[] in question [was] an infringement of states' rights.

See also Cross, supra note 4, at 1307 ("[F]ederalism is consistently . . employed only derivatively, as a tool to achieve some other ideological end, rather than as a principled end in itself."), 1323 ("Every justice [in Alden] voted consistently with the ideological dimension, wholly independent of federalism.").

131. Indeed, given the frequency with which the Court has reviewed the application of the FLSA to the states, one would expect at least one opinion to argue the consequences of the Court's holding here: that a state could resist individual suits arising under the FLSA on the basis of sovereign immunity, even if the application of the FLSA to states is constitutional. Yet not one opinion has done so. See Garcia, 469 U.S. at 528; Nat'l League of Cities, 426 U.S. at 833; Maryland v. Wirtz, 392 U.S. 183 (1968). 
enforcement of these laws that led Congress to confer a substantive right to sue upon individuals. ${ }^{132}$ In essence, individuals whose federal rights are violated by a state become private attorneys general. In seeking their own redress, they prevent future deprivation of rights. Assuming that enforcement by the federal government can give sufficient effect to these rights presupposes a federal enforcement power that simply does not exist. In this regard, the concern for the viability of the constitutional structure arises on three fronts.

\section{Infringement of Federal Power}

Alden undermines the federal government's ability to carry out functions that the Supreme Court has held to be within its delegated powers. If the federal government cannot enforce certain laws effectively agamst a state, its legitimacy could be undermined in the eyes of the people. As Justice O'Connor has noted, this is no small matter: "If [the federal system] is to be effective, there must be a proper balance between the States and the Federal Government. These twin powers will act as mutual restraints only if both are credible. In the tension between federal and state power lies the promise of liberty."

Furthermore, the prohibition on the use of individuals as private attorneys general raises the core functions analysis in reverse. If federal resources must be devoted to enforcement against states, they must naturally be diverted from other areas deemed important by the federal electorate. By forcing the federal government to redistribute its resources, Alden has the potential to undercut not only federal enforcement of Article I laws, but other areas of federal power as well. ${ }^{134}$

In addressimg this same concern with respect to a state's ability to carry out its powers within the federal scheme, Justice Kennedy commented: "When the Federal Government asserts authority over a State's most fundamental political processes, it strikes at the heart of the political accountability so essential to our liberty and republican form of government."135 Surely the same must be true when a state interferes with the federal government's ability to exercise its delegated powers. In sum, unless the majority is correct in its assessment that good faith will lead states to bow to the unenforceable will of the federal government, Alden

132. Alden, 527 U.S. at 810.

133. Gregory v. Ashcroft, 501 U.S. 452, 459 (1991).

134. Despite Justice Kennedy's reliance on this analysis to validate state sovereign immunity, the analysis itself cuts both ways. Under either outcome, immunity or no immunity, either the federal government or the states will face a fiscal impact that could force a redistribution of resources; one side or the other will face the possibility of having its ability to carry out its powers within the constitutional structure undermined. As a result, I do not believe that the redistribution of resources argument carries significant weight either in favor of or in opposition to state sovereign immunity relative to federal laws. Nevertheless, the potential impact on federal power is rcal.

135. Alden, 527 U.S. at 751 . 
could cause power to accrue to the states at the expense of the federal government, undermining the faith of the people and the legitimacy of the constitutional structure.

\section{Disenfranchisement of the People}

Although Justice Kennedy's self-proclaimed objective was to preserve the constitutional structure envisioned by the founding generation, ${ }^{136}$ he violated fundamental American constitutional principles by aggregating power to the federal government at the expense of the people. In New York v. United States, Justice O'Connor stated that 'the Constitution divides authority between federal and state governments for the protection of individuals." ${ }^{137}$ In the case of Article I power, it is the federal government that protects individuals against the exercise of state power. The strength of this protection, and thus the safety of the people, attains its zenith when the individual harmed determines for herself whether or not to take her case to court; when the individual, and not the government, determines whether the deprivation of rights rises to the level of an offense worthy of enforcement. Because the federal structure is designed to protect the people, not the states for their own sake, state consent to valid federal regulation in this context is irrelevant. ${ }^{138}$ Moreover, the Alden majority gives the federal government the power to waive an individual's rights under federal law by placing enforceinent of those rights at its sole discretion. Given that the object of the Constitution is to protect the rights of citizens from encroachment by both state and federal governments, this result is a significant step backward.

\section{Invalidation of Individual Expectations}

The experience of John Alden illustrates how the combination of Alden and Seminole Tribe can invalidate individuals' expectations of federal protection. John Alden believed that the FLSA meant what it said: that he was entitled to litigate his overtime claim against the State of Maine. ${ }^{139}$ Twice, John Alden went to court seeking redress for alleged violations of his rights. Twice he was turned away without a hearing on the merits of his claim, first by a federal court that was not empowered to hear his claim, and second by a state court that was not obligated to do so. For nnspecified reasons, the executive branch of the federal government elected not to pursue his claims on his behalf. The FLSA, a constitutional act of

136. Id. at 758 ("We seek to discover, however, only what the Framers and those who ratified the Constitution sought to accomplish when they created a federal system.").

137. 505 U.S. 144,181 (1992).

138. Id.

139. See 29 U.S.C. $\S 203(\mathrm{e})(2)(\mathrm{C})$. 
Congress, gives John Alden a right to a hearing on the merits of his claim. That he will never receive such a hearing is all too clear.

This is simply unfair and unwise, for the disruption of individual expectations will give rise to the legitimacy questions outlined above, weakening the federal system. Had the Court simply overturned Garcia, John Alden would still find himself without redress. But the expectations of many litigants to come would coinport with the certain outcome of their cases. Just as importantly, the federal government's power and its ability to exercise that power effectively would be in accord. ${ }^{140}$

\section{CONCLUSION}

Alden v. Maine is a disconcerting case for many reasons. The effect of the decision may undermine the federal government's ability to exercise its delegated powers. The decision certainly disenfranchises the very individuals whoin the Constitution seeks above all else to protect. And it exacerbates this already difficult situation by invalidating firm expectations backed by federal law.

Most troubling, however, is that Justice Kennedy failed in each of his three main arguments-original intent, constitutional structure, and the practical impacts of abrogation on states-to prove convincingly that the abrupt departure from Blackstone's wisdom that a right necessitates a reinedy ${ }^{141}$ is warranted, let alone compelled. That Blackstone's observation underscored American jurisprudence for more than 200 years is not surprising, for a right that cannot be enforced effectively is a worthless right. That a majority of the Supreme Court would cast away such a fundamental truism without being compelled to do so is surprising. Perhaps a limitation imposed by the Constitution could justify this harsh result, but Justice Kennedy has failed to prove that such a constitutional limitation exists.

140. Although it may be surprising in light of iny criticism of the majority, I believe that overturning Garcia would have been the correct result in Alden. The peculiar balance of power implemented in the Constitution, I believe, vests states with some aspect of sovereignty that cannot be usurped by Congress. Despite the Garcia Court's (perhaps rightful) rejection of the "core functions" analysis as an unworkable means to determine the scope of this sovereignty, the power to establish a government, including the power to locate a capital and establish a governmental framework, of whicli the rate paid to and hours worked by government einployees is a critical component, should be found to be within a sta+e's unassailable sovereignty, whatever test is applied. Nevertheless, I would rather see the FLSA enforceable by private actions against states than witness the abandonment of the "right equals remedy" premise to effectuate a National League of Cities world. The primary objective of the Constitution is to protect the people against both the federal and state governments, and for the reasons outlined above, under Alden the people lose.

141 See supra text accompanying note 1 . 
[Vol. 89:183 